\title{
NUMERICAL SIMULATION OF MOVING VEHICLE ACROSS THE OBSTACLE
}

\author{
L'uboš DANIEL $^{1,{ }^{*}}$ Veronika VALAŠKOVÁ ${ }^{1}$, Ján KORTIŠ ${ }^{1}$ \\ ${ }^{1}$ Department of Structural Mechanics, Faculty of Civil Engineering, University of Žilina, Univerzitná \\ 8215/1, 01026 Žilina. \\ * corresponding author: lubos.daniel@fstav.uniza.sk.
}

\section{Abstract}

Vehicle excitation by passing over pavement unevenness represents the actual problem which is solved on many departments in this time. The numerical methods are mainly applied for the solutions of the interaction of similar systems. The Finite Element Method (FEM) is the best-known and widely used. It provides appropriate accuracy. In this article, commercial computer software ADINA based on the FEM is used to solve kinematic excitation of vehicle. The $2 \mathrm{D}$ model of vehicle which represents real type of lorry T-815 is excited by simulation of passage across obstacle. There are compared dynamic responses of the vehicle on the kinematic excitation at different sneens.
\end{abstract}

\section{Keywords:}

ADINA; Dynamic interaction; Vehicle model; Finite element method.

\section{Introduction}

The pavement unevenness is the main source of kinematic excitation of the vehicle. Their significant effect on the size of the contact forces is between the pavement and vehicle. This is the reason to deal with. The successful resolution of the problem usually consists of theoretical and experimental solution. The theoretical solution is based on the FEM. FEM has been mostly used since computers calculation started as one of the possible way to find solution on systems of differential equations. In this case, the vehicle moved on the pavement and overcome obstacle among nonstationary dynamic actions. These actions are described by the following differential equation:

$$
[\boldsymbol{M}] \cdot\{\ddot{\boldsymbol{u}}(t)\}+[\boldsymbol{C}] \cdot\{\dot{\boldsymbol{u}}(t)\}+[\boldsymbol{K}] \cdot\{\boldsymbol{u}(t)\}=\{\boldsymbol{F}(t)\},
$$

where $[\mathbf{M}],[\mathbf{C}]$ and $[\mathbf{K}]$ are mass, damping and stiffness matrices. This describes the spatial properties of the vehicle, pavement and obstacle.

Newmark's method is widely used to do dynamic numerical simulation that was decided to use for solution of equations per time. This method is called implicit, because the solution at time $t+\Delta t$ is not explicitly determined by the state at time $t$. The relations between displacement, velocity and acceleration are governed by the following equations:

$$
\begin{aligned}
& \left\{\dot{\boldsymbol{u}}_{t+\Delta t}\right\}=\left\{\dot{\boldsymbol{u}}_{t}\right\}+\left[(1-\delta) \cdot\left\{\ddot{\boldsymbol{u}}_{t}\right\}+\delta \cdot\left\{\ddot{\boldsymbol{u}}_{t+\Delta t}\right\}\right] \cdot \Delta t, \\
& \left\{\boldsymbol{u}_{t+\Delta t}\right\}=\left\{\boldsymbol{u}_{t}\right\}+\left\{\dot{\boldsymbol{u}}_{t} \cdot \Delta t\right\}+\left[\left(\frac{1}{2}-\alpha\right) \cdot\left\{\ddot{\boldsymbol{u}}_{t}\right\}+\alpha\left\{\ddot{\boldsymbol{u}}_{t+\Delta t}\right\}\right] \cdot \Delta t^{2} .
\end{aligned}
$$

As a result, the time is also discredited and the solution is given in a form of the functional values. It is also included for all defined geometrical points in every time step. The different value for the time step affects the quality of the obtained results. It is very important to choose the right value of the time step.

In the article, a numerical 2D model of the vehicle as well as pavement and obstacle are created using computer software ADINA [1]. The computer software ADINA offers all options that are in demand. It offers the determination of contact pairs between the elements of vehicle that ensured the interaction between the pavement and the vehicle. Contact pairs are defined as target elements and contact elements in the computer software ADINA. The overall system is shown in the Fig. 1. 


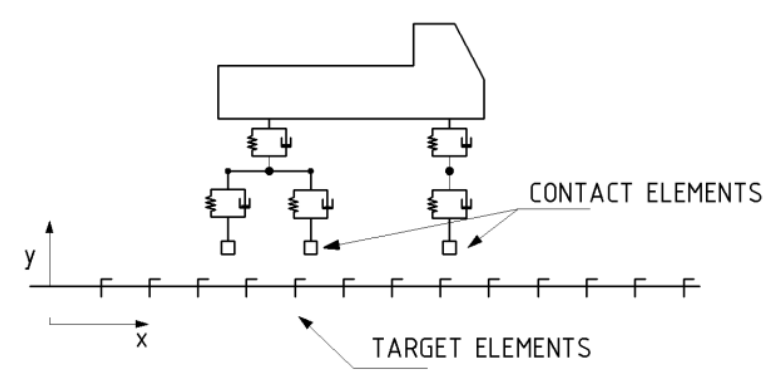

Fig. 1: Contact elements in the numerical model.

\section{Numerical model of vehicle}

The important part of simulation is to choose the appropriate model of vehicle. Model has to be represented with appropriate mathematical formulation. Half-part model are usually preferred and used for 2D analysis as a combination of mass, spring and beam elements. This discrete model of the vehicle with finite degrees of freedom makes solution easier from the mathematical point of view. This assumption changes partial differential equations to the ordinary differential equations. Half part model of lorry T-815 (Fig. 2) is used in this article.
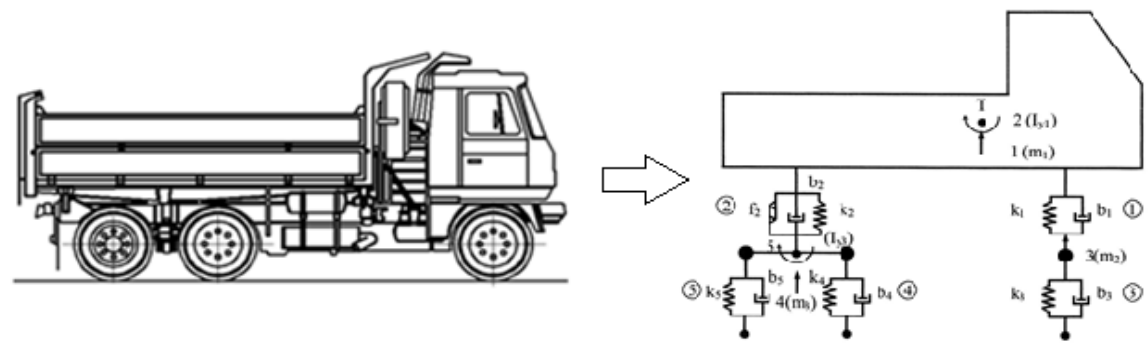

Fig. 2: Half-part model of lorry T-815.

The main characteristic of the half part model is defined by the three diagonal matrices. They are the mass $\{\mathbf{m}\}$, stiffness $\left\{\mathbf{k}_{\mathbf{i}}\right\}$ and damping $\left\{\mathbf{b}_{\mathbf{i}}\right\}$ matrices, which contain experimentally measured values [4].

$\left\{\mathbf{m}_{\mathrm{i}}\right\}_{\mathrm{D}}=\left\{m_{1}, l_{\mathrm{y} 1}, m_{2}, m_{3}, l_{\mathrm{y} 3}\right\}_{\mathrm{D}}=\{11475 ; 31149 ; 455 ; 1070 ; 466\}_{\mathrm{D}}$

$\left\{\mathbf{k}_{\mathbf{i}}\right\}_{\mathrm{D}}=\left\{k_{1}, k_{2}, k_{3}, k_{4}, k_{5}\right\}_{\mathrm{D}}=\{143716.5 ; 761256 ; 1275300 ; 2511360 ; 2511360\}_{\mathrm{D}}$

$\left\{\mathbf{b}_{\mathrm{i}}\right\}_{\mathrm{D}}=\left\{b_{1}, b_{2}, b_{3}, b_{4}, b_{5}\right\}_{\mathrm{D}}=\{19228,260197,2746,5494,5494\}_{\mathrm{D}}$

$\left(\mathrm{kg}, \mathrm{kg} \cdot \mathrm{m}^{2}\right)$,

Natural frequencies determined as a result of the experiment are consistent with the calculating natural frequencies.

$\{\mathbf{f}\}=\left\{f_{(1)} ; f_{(2)} ; f_{(3)} ; f_{(4)} ; f_{(5)}\right\}=\{1.13 ; 1.45 ; 8.89 ; 10.91 ; 11.71\}$

$(\mathrm{Hz})$.

\section{The model of pavement with obstacle}

The obstacle is defined on a surface of pavement. The pavement and the obstacle are modelled as a rigid surface. The pavement is composed with the surface for an acceleration $(15 \mathrm{~m})$, the obstacle $(1.2 \mathrm{~m})$ and a surface for breaking $(15 \mathrm{~m})$ (Fig. 3). Shape of the obstacle is similar to the shapes that are recommended for a dynamic test of bridges. This shape is also identical with retarders on the pavement. 


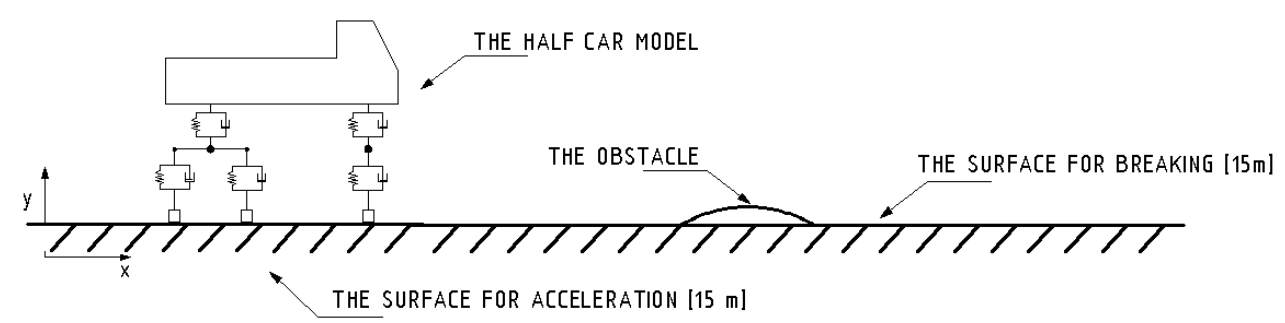

Fig. 3: The numerical model of the vehicle and obstacle.

For better convergence of the numerical solution, the obstacle was modelled as a function:

$\boldsymbol{h}(\boldsymbol{x})=h_{0}\left\{1-\cos \left[2 \pi x /\left(2 l_{0}\right)\right]\right\} / 2$,

where: $h_{0}=0.06 \mathrm{~m}$,

$2 \times I_{0}=0.940 \mathrm{~m}$, (Fig. 4).

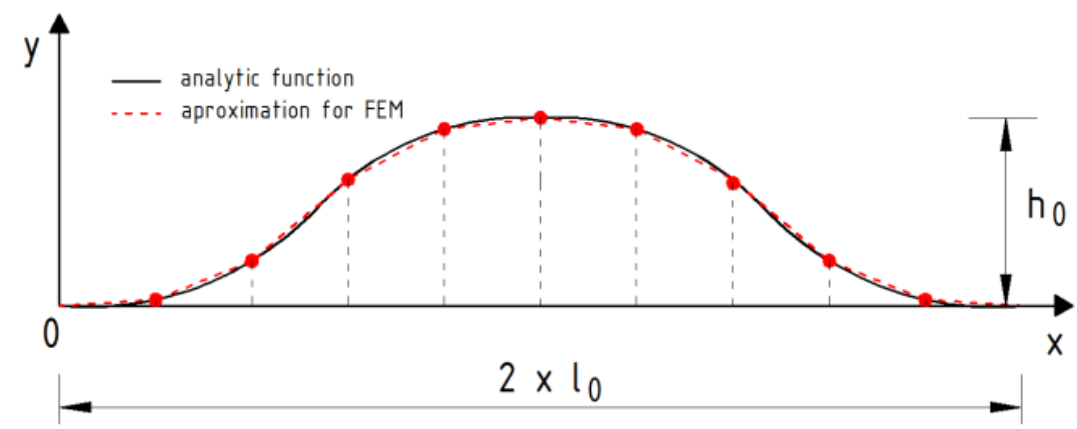

Fig. 4: The shape of the obstacle.

\section{Results}

The vehicle passes across the obstacle in a constant speed during the all simulation. The speeds were 10,15 and $20 \mathrm{~m}_{\mathrm{s}} \mathrm{s}^{-1}$. The deflections on three parts of vehicle are monitored, namely centre of gravity, front axle and rear axle (Fig. 5).

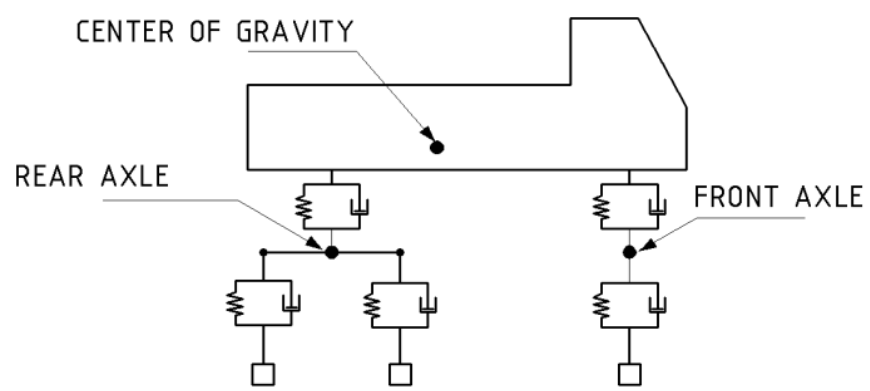

Fig. 5: The monitored points on the vehicle.

The time step of numerical integration is $1 / 20$ of a second. The time when the vehicle passes the obstacle is changed to $1 / 100$ of a second to obtain better results. The following figures show the defection in the centre of gravity (Fig. 6), a front axle (Fig. 7) and a rear axle (Fig. 8). 


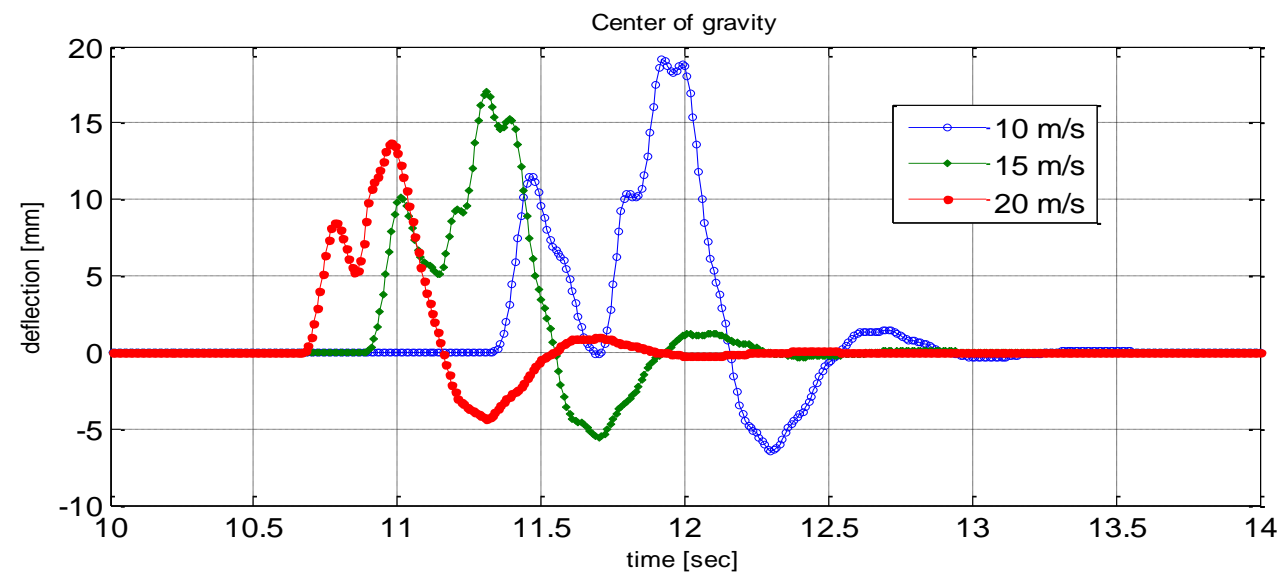

Fig. 6: The deflection in the center of gravity of the vehicle.

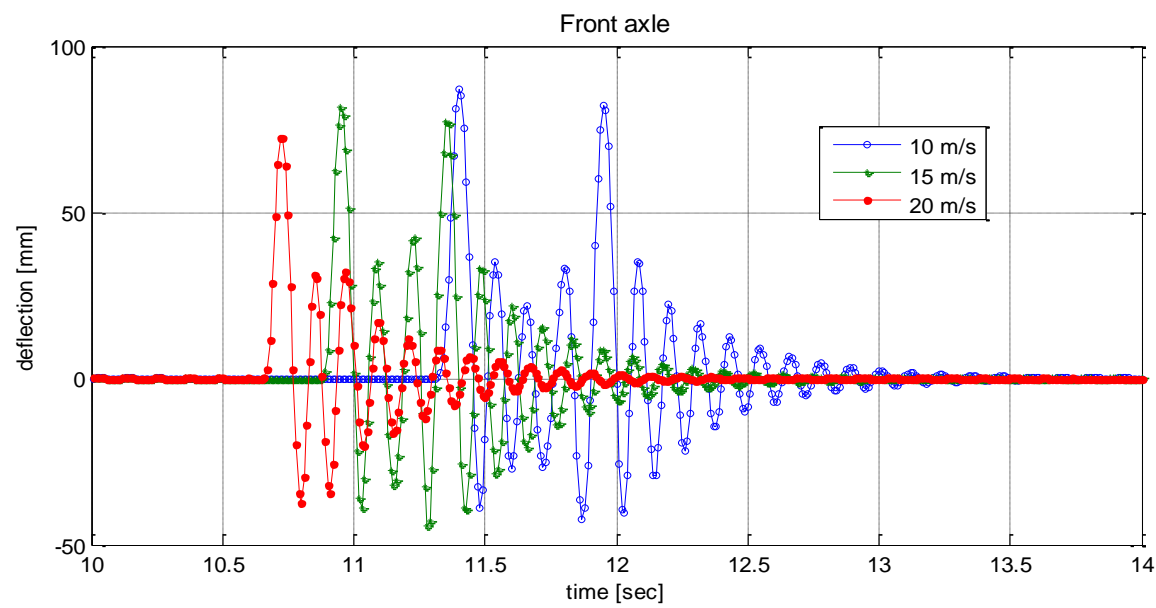

Fig. 7: The deflection in the front axle of the vehicle.

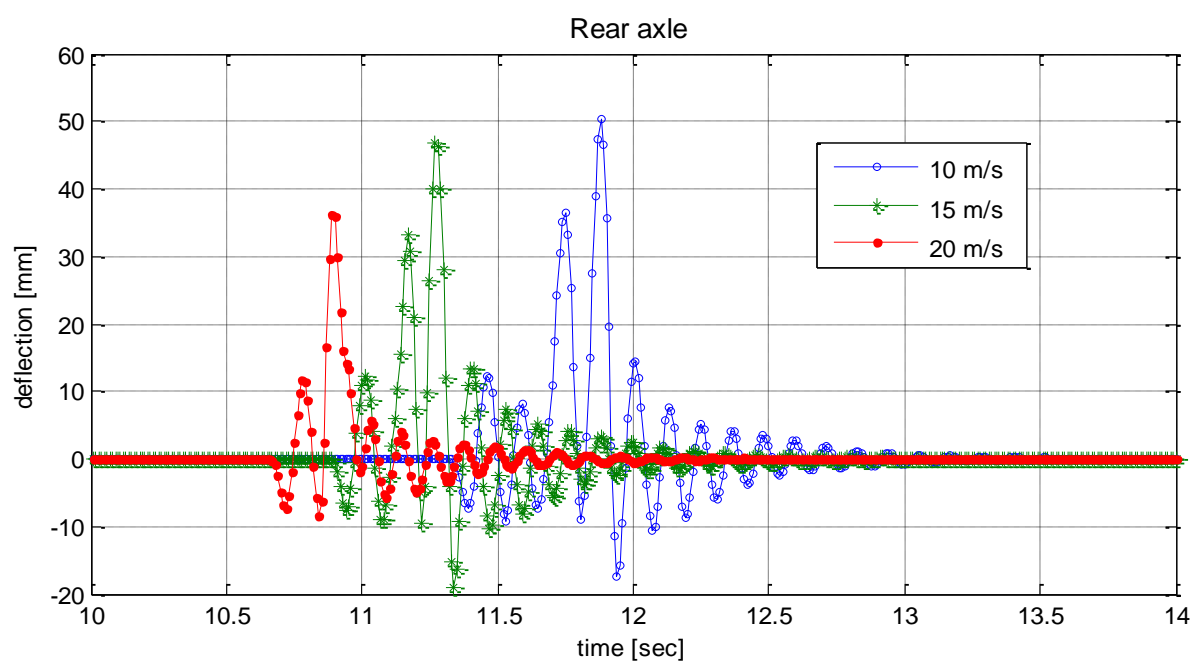

Fig. 8: The deflection in the rear axle of the vehicle.

\section{Conclusions}

The article shows that the use of FEM can give good results for numerical analysis of the problem. The results of simulations also reveal the variations of amplitudes of deflection in 
observed points that are driven by the increasing speed of passing vehicles. The reason is that the inertial effects of the moving vehicle in the higher speeds fail to respond on the kinematic excitation. The plans for next steps of research are to compare the results of numerical simulations with experimental measurements.

\section{Acknowledgement}

This contribution is the result of the research supported by GA MŠVVaŠ SR VEGA, grant num. 1/0259/12.

\section{References}

[1] BATHE, K. J.: Finite Element Procedures. Cambridge, MA: Klaus - Jürgen Bathe, 2006.

[2] LAJČÁKOVÁ, G. - MARTINICKÁ, I. - MELCER, J. - DANIEL, L'.: Influence of pavement unevenness on its straining. In: Civil and environmental engineering, vol. 8, 2012, no. 1, p. $63-$ 77, ISSN 1336-5835.

[3] DANIEL, L'.: Vehicle-road interaction (Interakcia v sústave vozidlo - jazdná dráha), Práca ŠVOČ, SvF, ŽU, Žilina, 2012.

[4] MARTINICKÁ, I.: Výpočet vlastných frekvencií a tvarov vlastného kmitania výpočtových modelov vozidiel, In: Pozemné komunikácie a dráhy. ISSN 1336-7501. Roč. 6, č. 1-2 , s. 41-50, 2010.

[5] FRÝBA, L.: Vibration of Solids and Structures Under Moving Loads. ACADEMIA, Praha, Nordhoff International Publishing, Groningen, 1972.

[6] BENČA, Š.: Výpočtové postupy MKP pri riešení lineárnych úloh mechaniky, Strojnícka fakulta STU v Bratislave, 2005. 